\title{
Small-Scale Irrigation in a Multiethnic Oasis Environment: the Case of Zaouit Amelkis Village, Southeast Morocco
}

\author{
Hsain Ilahiane
}

\section{Introduction}

In light of recent attention to sustainability, much of the development literature stresses indigenous resource management strategies for solving the plight of the poor and vulnerable in Africa. Much care is needed when assessing the vulnerability of the poor and advocating the rehabilitation of indigenous or home-grown institutions to protect the community from social and natural perturbations; these same institutions may act as potential barriers to any well- intentioned development effort (E. Arnould 1990:10-11; R. Chambers 1989:1-2). Indigenous communities are not always as benign or as egalitarian as the literature tends to describe them. Rather, they are often conflict-ridden entities in fierce competition over marginal and scarce resources: in this case, traditional sources of irrigation. In the Ziz Valley, located in southeast Morocco, irrigation management can only be understood through a historical examination of the ethnopolitical relations among social groups and the ecological relations governing the organization of, and access to, resources.

This paper describes a locally managed and maintained small-scale irrigation system in the middle Ziz Valley oasis with particular focus on the village of Zaouit Amelkis. The village of Zaouit Amelkis is one of the sites where the author conducted dissertation fieldwork on the relationship between ethnicity and agricultural intensification in 1994 and 1995. The Amelkis community is composed of three ethnic groups: Berbers, Arabs, and Haratine. The population of the village is 1,296 making up 193 households, 10 percent Berber, 8 percent Shurfa and Murabitin Arabs, and 82 percent Haratine. The local economy is based on irrigated subsistence agriculture, the tending of date and olive trees, and livestock raising. The farming population mainly cultivates barley, wheat, corn, alfalfa, turnips, carrots, fava beans, and various fruit trees. Dry farming or lbur is also practiced in rainy years for growing cereals, particularly wheat and barley in the surrounding hills. The Amelkis village is characterized by land differentials among its ethnic groups. The entire village farming land is 163.5 hectares, 33 percent Berber, 20 percent Shurfa and Murabitin Arabs, 22 percent Haratine, 15 percent outsiders, and 10 percent mosque or waqf (H. Ilahiane 995).

This paper argues that the village of Zaouit Amelkis provides a case study where small-scale irrigation maintenance has been based on labor extortion from the low-status Haratine by the high- status Berbers and Arabs. This paper describes: (1) the environment of the Ziz Valley, (2) the Ziz Valley's society of rank, (3) the irrigation system of the 
village of Zaouit Amelkis, and (4) the social organization of the Zaouit Amelkis' irrigation system.

\section{The Environment of the Ziz Valley}

To the south of the eastern High Atlas mountains, one encounters a rugged region composed of high elevation mountains of a south western-south eastern slope riding over the Sillon Sud Atlassique chain, sandwiched between the Anti-Atlas and the Hammada of Meski and Guir. In the middle of these arid mountains, the Ziz valley is the richest and most populated area (Figure 1). Born on the southern slopes of the Jbal Ayash $(3760 \mathrm{~m}$ ), the Oued Ziz meanders through a 200-km ribbon of olive trees, date palms, cereals, and alfalfa fields. The river, 30 to $60 \mathrm{~m}$ wide and of variable depth, covers the area between upper Rich and the low lands of Rissani. Along the Oued, myriad springs feed its course. In fall and spring, the river is subject to violent flash floods that damage property and fields. To the west of Rich, another geological cut leads to the High Atlas massif of yearround, snow-capped mountains of the upper Ziz valley reaching an elevation of $3000 \mathrm{~m}$ around the Imilchil and Zawit Sidi Hamza rural communities. To the west of Errachidia, a flat plateau dotted by the Jbal Afardou takes the eye to the little valley of Tarda in the direction of Goulmima.

The Ziz Valley is narrow in its upper stretches. The Oued runs through a twisting course of high walled gorges, characterized by an unshouldered and paved road for $70 \mathrm{~km}$ between Rich and Errachidia. The inhabitants of the valley live in ksars or villages. These villages are large, squared structures built of adobe, sun baked earthen bricks and stone, with high walls reaching 4-5 $\mathrm{m}$ in height, with four or six watch towers built to guard the inhabitants, the palm grove, and livestock against the pillage and violence of marauding tribes of the Saharan fringes in precolonial times.

To the south of Errachidia, the Oued Ziz winds through the District of Mdaghra (21 km long) and continues to snake its way only to make an abrupt entrance upon the Middle valley and the District of Aouffous (Rteb) between the ksars of Zaouit Amelkis and Dwira, a distance $35 \mathrm{Km}$. The dry belt separating Rteb from Erfoud makes the Irdi plateau, an area full of sandy hills. To the North of Erfoud, the valley enlarges; the river enters El M'adid and Tizimi palm groves, respectively. The Ziz River continues its journey to the south where it runs parallel to the Ghris River coming from the west. At this point, the Ziz arrives at the Tafilalet plain. The Tafilalet is the most important palm grove of the region from which southeast Morocco has historically taken its name. This region is of a pear shape and irregular, with a north-south axis of approximately $30 \mathrm{Km}$ and an east-west axis of $20 \mathrm{Km}$. The entire region is an alluvial plain. It is irrigated by the Ziz and Ghris rivers. To the south of the Tafilalet plain, a salinized sheet covers the area making vegetation growth impossible.

The lower valley of Ziz is characterized by ponds around Merzougua at the foot of the Erg Chebbi, a huge composite of lined up golden sand dunes, 100 to $150 \mathrm{~m}$ high occupying an area no larger than $100 \mathrm{Km}^{2}$ overlooking a flat plain and covered by a sheet of black soil and stones called the Reg. The Ziz continues its way through this dry bed, drifting into the Saharan plains whose primary function, at this conjunction, is to channel flood waters. Finally, The Ziz meets the Oued Ghris a few kilometers north of Ramlia only to depart in unison to flow into Oued Daoura in the heart of the Kem-Kem Hammada. The Ziz drains approximately $14,125 \mathrm{~km}^{2}$, a watershed with an average altitude of about 1100 $\mathrm{m}$. 
The Ziz Valley is part of the vast and intimidating Sahara Desert. Although the harsh environment south of the High Atlas mountains does not prohibit human habitation, the region is arid. Along with diminishing relief and elevation from north to south, average annual precipitation decreases approximately $50 \mathrm{~mm}$ with every $100 \mathrm{~m}$ of descent. About $250 \mathrm{~mm}$ fall in an average of 70 days on the highest areas; fewer than 25 days of precipitation produce less than $50 \mathrm{~mm}$ in the far south. Dry farming is impossible in most years throughout the Errachidia province. Approximately 80 percent of the region's precipitation, mostly rain, accumulates during intense autumn (September-December) and spring (February-May) storms.

Temperatures vary from $-5^{0} \mathrm{C}$ to $40^{\circ} \mathrm{C}$, with an annual average daytime high of $20^{\circ} \mathrm{C}$. The typical frost-free growing season begins in early March and continues well into November. Hot chergui winds blow out of the Sahara from the east between March and May, and scorching southwesterly sirocco winds bring clouds of dust and sand during the months of September and October. These winds intensify evapotranspiration and can cause widespread crop damage, especially to date and olive groves. Annual potential pan evaporation rates in the region are about $1280 \mathrm{~mm}$ on cultivated soils and $834 \mathrm{~mm}$ on undisturbed lands (ORMVAT 1991).

Climatic factors have a tremendous impact on crop productivity throughout the study region, and this influence increases toward the south. In 1979-1980 (the agricultural year begins in the fall), a good year in the Tafilalet Plain, about 83 percent of the arable land was cultivated; the following year, 1980-1981, only about 43 percent of Tafilalet lands were under crops. In the middle Ziz Valley, with its many reliable springs, farmers were able to irrigate about 81 percent of their arable land during both years (ORMVAT 1989:24-25).

Soil formation in the Ziz Valley is retarded by arid conditions. Nevertheless, Ziz flood waters have deposited thick, fertile sediments. As the Ziz River and other major streams flow out of the mountains and become less constricted, their floodplains become broader, and arable alluvial deposits become deeper. Ziz farmers employ a soil taxonomy that includes 6 classes. Lhlu (sweet) soils are a mixture of sand and deposits of silt. Relatively deep, rich in nutrients and fertile, and they are widely cultivated they are easy to till and have good water storage potential, requiring irrigation once every four to six days. L'aqad (reddish-brown) soils are similar to lhlu but are compact, and less rocky and drought resistant. They are considered to be the most productive soils and sought enthusiastically by farmers. They take less fertilizer than the other soils and "are productive no matter how stingy one gets with the application of expensive fertilizer and manure and require less labor attention", a farmer conceded. L'aqad is irrigated once every 15 to 20 days and is thus superior for agricultural uses. Mramel (sandy soils) dominate the Ziz banks but are less desirable because of their need for more frequent irrigation, at least once every four days. Lharsh (angular gravel) soils dominate the unworked foot of the mountains and areas of the Oued's banks and floodplain. The lharsh fields are not as productive as l'aqad or lhlu. They are drought prone, and in order for them to be productive, large amounts of sand, silt, and green manure must be added. Lmalh (salty) soils are not desired by most farmers but tolerated. They are sites of fields filled with pans of salt. To render them productive farmers are obliged to practice preirrigation to flush out the salt deposits, and to turn the soil to bake in the sun every year before planting. Finally, Lmsus (unsalty) soils are the least desirable by farmers. They occupy waterlogged areas and are subject to too much shade (H. Ilahiane 1995). 
Water in the valley is supplied by flood waters, springs, wells, river resurgences, khottarat (qanats), diversion dams, and the 380,000,000 $\mathrm{m}^{3}$ Hassan Addakhil storage reservoir. The river drainage basin supplies the reservoir with an annual average input of $164,000,000 \mathrm{~m}^{3}$. Table 1 summarizes some quantitative data for these sources.

TABLE 1. Ziz Valley Water Supply

\begin{tabular}{|c|c|c|c|}
\hline Source $^{\mathrm{a}}$ & Number & Output $^{\mathrm{b}}$ & Notes \\
\hline $\begin{array}{l}\text { Oued Ziz via } \\
\text { Hassan Addakhil }\end{array}$ & na & $141.4 * *$ & $\begin{array}{l}\text { Controls Ziz } \\
\text { flow, supplies "Grande } \\
\text { Hydraulique" network }\end{array}$ \\
\hline $\begin{array}{l}\text { Meski Spring } \\
\& \text { Resurgences }\end{array}$ & na & $24.6 * *$ & \\
\hline Artesian wells & na & $3.6 * *$ & \\
\hline Private Wells & 5000 & na & \\
\hline ORMVAT Wells & 7 & 9,964 milliliters & 492 ha irrigated \\
\hline $\begin{array}{l}\text { Cooperative } \\
\text { Pump stations }\end{array}$ & 60 & 460 liters/second & $\begin{array}{l}\text { Some have ceased } \\
\text { operations }\end{array}$ \\
\hline Khettarat (qanats) & 376 & 0.9 & $\begin{array}{l}\text { Avg. flow }=30 \mathrm{l} / \mathrm{s} ; \text { In } \\
1990 \text { only } 144 \\
\text { operating }\end{array}$ \\
\hline Floodwater & na & $24.0 * *$ & $\begin{array}{l}\text { Less common since } \\
1971 \text { below modern } \\
\text { dam }\end{array}$ \\
\hline $\begin{array}{l}\text { Oued Ghris via } \\
\text { Moulay Brahim } \\
\text { Diversion }\end{array}$ & na & $95.0 * *$ & $\begin{array}{l}17 \mathrm{Km} \text { Laghrissia } \\
\text { canal to Tafilalet Plain }\end{array}$ \\
\hline TOTAL & na & $292.96 * *$ & $\begin{array}{l}\text { Stabilized + average } \\
\text { annual figures }\end{array}$ \\
\hline
\end{tabular}

a. Sources: ANAFID 1990, 1991; ORMVAT 1989; Ilahiane, Mabry and Welsh 1991

b. ** million $\mathrm{m}^{3}$ per average year.

The Hassan Addakhil Dam, completed in 1971, was a response to a November 1965 flood of $5,000 \mathrm{~m}^{3} / \mathrm{s}$ that disabled most bridges below Rich and caused widespread field and crop losses. The valley's farmers also remember major destructive floods in 1949 and 1925. The dam demonstrated its value in 1989 and 1994 by capturing floods that knocked out roads and caused other damage above the reservoir, in the Kheng and Guers Tiallaline region. In addition to floods, droughts, sandstorms, salinization, sand dune encroachment, the date palm fungus known as lbayoud, locusts and other pests are important limiting factors in the region's agriculture.

A primary canal form the Hassan Addakhil Dam flows on the west bank of the Oued Ziz to irrigate the area extending from the foot of the dam to Targa and the New Perimeter villages. The east bank primary irrigates a perimeter extending to Meski. The Meski spring supplies 10-15 million $\mathrm{m}^{3}$ annually to lands controlled by the communities of Meski, Bousaid, Lkenz, Zaouit Amelkis, Jramna, and Zwiwia. In response to the severe 
drought (1979-1986), the regional office for agricultural development and water management (ORMVAT) established 17 additional groundwater pumping stations to supplement the dwindling river flows and built and refurbished the Lahmida and Laghrissia canals to transfer flood waters from the Ghris Oued to the Ziz to irrigate the Tafilalet plain.

According to the 1994 census, the population of Errachidia province is 522,017, 42 percent urban and 58 percent rural. Population density is 10.8-22.4 per cultivated hectare, 5.1 per uncultivated hectare, and 2 per square kilometer for the rest of the province. Sixty percent of the province's population is engaged in full and part-time farming; the rest is involved in construction, government, commerce, national and international migration (Europe), and services (Ministère du Plan 1995).

Agricultural resources are concentrated mainly in cereal cultivation, arboriculture, and livestock. The area available for the practice of farming is 43,069 hectares and the potential area covers 48,069 hectares making up 45,000 farming household units. The average farmer's entire holdings total less than a hectare $(.86 \mathrm{ha})$, with about $65-70$ percent of his total holdings under cereal cultivation (.6 ha) and the rest under alfalfa and seasonal vegetables or occupied by perennials, such as olive, fruit, and date palm trees. On the provincial level, the farming system is partitioned as follows: cereals occupying 60 percent of the farming area, barley 14 percent, fava beans percent, corn 9 percent, alfalfa 10 percent, vegetable gardens 2 percent, and henna and cumin 1 percent.

Arboriculture, mainly dates and olives, plays a crucial role in the economic development and ecological survival of the area accounting for 60 percent of household income. Livestock is the third important economic aspect of the valley's agriculture, with an average of 5 to 6 head of sheep per household (ORMVAT 1991).

In summary, the potential productivity of the region is restricted by climatic conditions affecting the resilience of the valley's irrigated farming. Water scarcity and its erratic variability over time and space, recurrent droughts, and frequent locust invasions have contributed to the impoverishment of the valley's environment. The lbayoud disease ravaging the date palm trees and the annual alternating olive production combine to reduce household welfare. All these factors have, in one way or another, impeded the optimization of the agricultural resources.

\section{The Ziz Valley: a society of rank}

For more than 12 centuries of recorded history the valley has been a theater of ethnic struggles, urbanization, and social change. Its medieval trade entrepot, Sijilmassa, which flourished from the caravan trade, slavery, and the trading of African gold, shaped the valley's environment and its historical relations of production.

In the seventeenth and eighteenth centuries, the history of Tafilalet or the Ziz Valley was marked by resource scarcity, drought, famine, and diseases. This scarcity and competition over resources by various nomadic tribes opened the door to the zawiyas to act as peace brokers. The religious lodges of the Shurfa and the Murabitin were rewarded by valuable gifts and economic favors by the surrounding tribes for resolving conflict among the nomads and sedentary communities. This period saw the rise of the Shurfa and Murabitin Arabs and other trading groups to the summit of the social and ethnic pyramid because of their involvement in the transaharan trade. The rise of the Ait Atta Berbers, natives of the Jbel Saghro due west of the Ziz Valley, was provoked when the Banu Ma'qil Arabs expanded to the west depriving the Ait Atta of their traditional Sijilmassa market 
and threatening their grazing lands. The Banu Ma'qil expansion would provoke a harsh reaction that changed the regional ethnopolitical balance of southeast Morocco. The Ait Khabbash's, a clan of the Ait Atta tribe, took possession of many villages that they still occupy today, an area covering the best watered lands along the Ziz Valley. Ethnic and ecological factors combined to facilitate this expansion: drought periods of the seventeenth and eighteenth centuries, the Banu Ma'qil's encroachment on Ait Atta's escort of the transaharan trade routes, and the latter's control of the Ziz and other palm groves (a source of economic exchange with the sedentary Haratine), and France's incipient control of the Sahara Desert (see L. Mezzine 1987).

The peoples of the Ziz Valley compose an ethnically-stratified society (of rank). The Shurfa Arabs are believed to be descendants of the Prophet Mohammed through the line of either Idriss al-Awal of Fez or Mulay Ali Sharif of Tafilalet. The former was the founder of the first Arab dynasty in Morocco in the eighth century; he founded the city of Fez in 892 AD. The latter was the founder of the Alawite Dynasty in the seventeenth century and still rules Morocco. They are entitled to a number of communal privileges and personal immunities.

The Murabitin are thought to be the descendants of holy men who were revered as saints. The living members of a saint's lineage are responsible for the maintenance of his shrine, and for the administration of gifts of money or sheep and goats donated by the followers of the saint. The difference between them and the rest of the population is their possession of baraka, the quality of divine grace. Because of their baraka, the Murabitin and the Shurfa serve as respected and credible men in decide and mediate communal and personal conflicts (see also E. Gellner 1969).

Berber status derives from their social organization, historical military dominance, and persistent political power, factors prompting Berber self-perception as a dominant social class.

Berber social organization is based on what structural-functionalist anthropologists call the segmentary lineage model. The notion of segmentation stresses the fact that order and peace are not maintained by specialized agencies or institutions of a state, but by the balanced opposition that unites forces and alliances in case of external menaces (E. Gellner 1969:41-44). Such societies are divided into subgroups, which in turn further divide, all groups at the same level of segmentation are in balanced opposition. Households are inserted into this system of segments and subsegments in a defined manner, and social ties of any sort are insignificant. Gellner stresses the absence of ambiguity in a segmentary society, he argues that this type of society it ensures that there will be groups in balanced opposition that can be mobilized in times of conflict. Most of these groups are not corporate, but rise to existence when in opposition to others (E. Gellner1969:116).

Another essential characteristic of Gellner's model of segmentation is the presence of the saints, who hold the segmentary partition of the Berber society in order. The Shurfa and the Murabitin, putative descendants of the prophet and holy saints, play the role of mediators among the Berber tribes of the High Atlas. The sacred cast of the holy mediators, according to Gellner (1969:54-55), allowed the Berber tribes to have a democratic system in which no one group dominated economically and politically.

Berber social organization is essentially a product of a transhumant society based on force and power. Its elementary social unit of analysis is the household or takat, and a number of households form what is called an igezdu. Households belong to lineages or ighsan. Villages may shelter different lineages, and often trace their genealogy to a 
common ancestor. Lineages belong to clans, and a number of clans make the taqbilt or a tribe. Tribes, in turn, shape confederations.

During the nineteenth century the middle Ziz came under the control of the Ait Atta. According to the local reconstruction of history, the Ait Atta, specifically the Ait Khabbash clan, entered the middle stretches of the Ziz, at the time when France embarked on its colonization of Algeria in 1830. The Ait Khabbash together with the Ait Umnasf in the Rtbat region occupied 16 villages by the end of the nineteenth century (R. Dunn 1977:93, 1972; L. Mezzine 1987). In the Rtbat region, the Ait Khabbash expelled most of the inhabitants and confiscated most of their lands and property. They also extended their power through domination over trade routes escorting caravans between Touat in southwest Algeria and Tafilalet and also practiced the "piracy of the road" (R. Dunn 1972). The first language of the Ait Atta is Tamazight, a Berber dialect.

The Ait Atta expansion was directed toward the control of agricultural resources more than the occupation of pastures. The Ait Atta did not regard Blacks or Arabs as their social or political equals. By 1912 and the beginning of the French Protectorate, the Ait Khabbash were firmly established in the Rtbat region.

The Haratine are allocated inferior status and are typically responsible for menial labor. Because traditionally they did not own land, they worked as sharecroppers for Arabs and Berbers. As for the Haratine's history, there are many versions. Local ethnohistory differentiates between slaves and the Haratine. Slaves were integrated into Berber and Arab households, whereas the Haratine never assumed that position. They have always been characterized as "the workers of the soil." From a linguistic perspective, the etymology of the word Haratine means many things and has evolved through time. From the root of the Arabic verb - haratha-, to plant, one can say that they were referred to by the conquering tribes as harathine or cultivators of land. This suggests that the Haratine might have been the ancient inhabitants of the Saharan frontier from the time of its desiccation. The other meaning is derived from breaking down the term Hartani into two components hor and thani, two separate words meaning the "second free people" (as opposed to freeborn Arab commoners). In Berber, however, the Haratine are referred to as iqbliyn, meaning the people of the east or the inhabitants of the southeastern oases, a term that could have been coined during the Berber take-over of the sedentary communities composed of Haratine and Arab commoners in the seventeenth and eighteenth centuries. Iqbliyn are, in turn, divided into iqbliyn imalalan or white easterners who own land, and iqbliy ungaln or black easterners who have no access to land and thus are subject to subordination, the Haratine. Iqbliyn imalalan are also called qbala, they are of Arab descent such as the Beni Hcine who populate a few villages around the Rich area. In other Berber dialects such as the one spoken by the Ait Sgherushen tribe, the term ahardan which is closer to the word Haratine refers to a person with a dark complexion. The term Haratine does not exist in Arabic. The Berber term apparently underwent an arabization process, transforming it from the original form of ahardan to the locally arabized version of Hartani. This linguistic evolution testifies to the arabization drive of Islam since the eighth century. Outside the Ziz Valley, the Haratine are referred to as drawa, natives of the Dar'a Valley, an oasis to the west of the Ziz Valley. The term 'azzi Bambara is generally used outside of the southern oases for slaves in reference to the Bambara people of the Sahel, brought to Morocco during the invasion of the Sudan by Sultan Ahmed Al Mansour Dahbi in 1591 AD (H. Ilahiane 1995).

In the valley's chain of ethnic stratification, the Arabs and the Berbers classify the racial and social status of the Haratine along at least 5 attributes: (1) their skin color, 
ahardan, implying black and not worthy of respect; (2) a landless condition, people of no al-asl, denoting lack of ancestry and shamelessness; (3) an obtuseness attribute meaning short of intelligence, "like donkeys," and infantile; (4) a patronage attribute, ait-tmurt or "our people" indicating protection pacts the Haratine were subject of; and (5) a labor attribute, sharecropper, naming any Hartani working on the lands of the people of al-asl in exchange for one fifth of the harvest. Before the advent of French colonialism, they were also deemed to be "like women" and not permitted to wear white turbans, the symbol of Ait Atta and holy Arab manhood. They were prohibited from participation in the village council of the Ait Atta, denied arms, and sometimes used as shooting targets for any Ait Atta member who wished to test his new gun (D. Hart 1980; D. Jacques-Meunié 1958).

\section{The Irrigation System of the Zaouit Amelkis Village}

The palm grove is the heart of the village of Zaouit Amelkis and its main source of subsistence. Concerns about the management of the palm grove and its irrigation system are the stuff of everyday life in the village. As a defensive strategy the village and its council crafted a bundle of rules to govern the use of the palm grove. The stipulations of customary law reported in written documents as in the ta 'qqit of the Lgara village and oral history testify to the determination of the Ait Atta Berbers to leave nothing to pure chance.

The palm grove has its chief, amghar n'tamazirt, to see to it that fields and produce are not subject to theft. The irrigation network has also its chief, amghar n-tiruggin, who supervises the cleaning and maintenance of the canals and the dam. The two chiefs are always Berber or Arab, and they are appointed by the council based on their age, honesty, and religiosity as these attributes are essential to the just management of the subsistence base. Communal institutions govern the agricultural calender and land use, and fix the opening and closing of date and olive harvests. The legal organization of farming sanctions severely acts such as unauthorized weeding on the borders of irrigation canals and the river, unauthorized gleaning of dates, olives and other fruit in the palm grove and around the gardens, bringing weeds or alfalfa into the village after sunset, and the picking of green wood.

Land use within the palm grove and around the village of Zaouit Amelkis follows a pattern of successive agricultural activities and zones. The first zone is the walled gardens located in front of the main gate and around the ramparts of the village. These gardens are used to grow vegetables and fruit trees; they are called urtan in Berber. The second zone is dedicated to the cultivation of alfalfa, and is characterized by the dominance of olive trees. The third zone is dominated by cereals, date-palm trees, and other types of trees. The fourth zone is comprised of the fields that are rarely irrigated; these field are almost devoid of trees. Here barley is planted in rainy years. These fields are known as communal or village lands. In the fifth zone are stretches of infertile land, al-'asi in Moroccan Arabic, used for grazing. This land is found outside the palm grove in the nearby hills and along the surrounding mountains and plateaus.

Ethnographies of water rights in rural Morocco have been traditionally confined to a simple interpretation and description of rules, whether these rules were based on the shari ${ }^{\prime} a$, introduced by the French and Spanish colonial administrators, or were a product of tribal customary law. Research on the relationship between the rules of water and social stratification has been ignored or only mentioned briefly in passing. Some anthropologists and other social scientists have tried to find the relationship between the social order and the way irrigation functions, and have correlated water distribution with segmentary 
models of various tribes. ${ }^{1}$ Hammoudi, writing on water rights and water distribution in the Dar'a Valley of southern Morocco, maps out the historical and ethnic dynamics that influenced the land and water tenure system. He discusses the impact of the religious status of the Arab Shurfa and Murabitin, the power of the Berber nomads, and the low social status of the Haratine on water distribution in the valley. Different from the Ziz Valley where water and land rights are joined resulting in what is called mulk or private ownership, Hammoudi discusses two systems of water distribution in the Dar'a Valley: the allam system, in which water is a common property and resembles the Ziz Valley's system; and the mulk, in which water is a commodity subject to market demands. According to Hammoudi, the difference between the two systems is that under the allam system a person is entitled to a water share to irrigate their fields; in mulk, water becomes a commodity sold and bought (A. Hammoudi 1985:39-41).

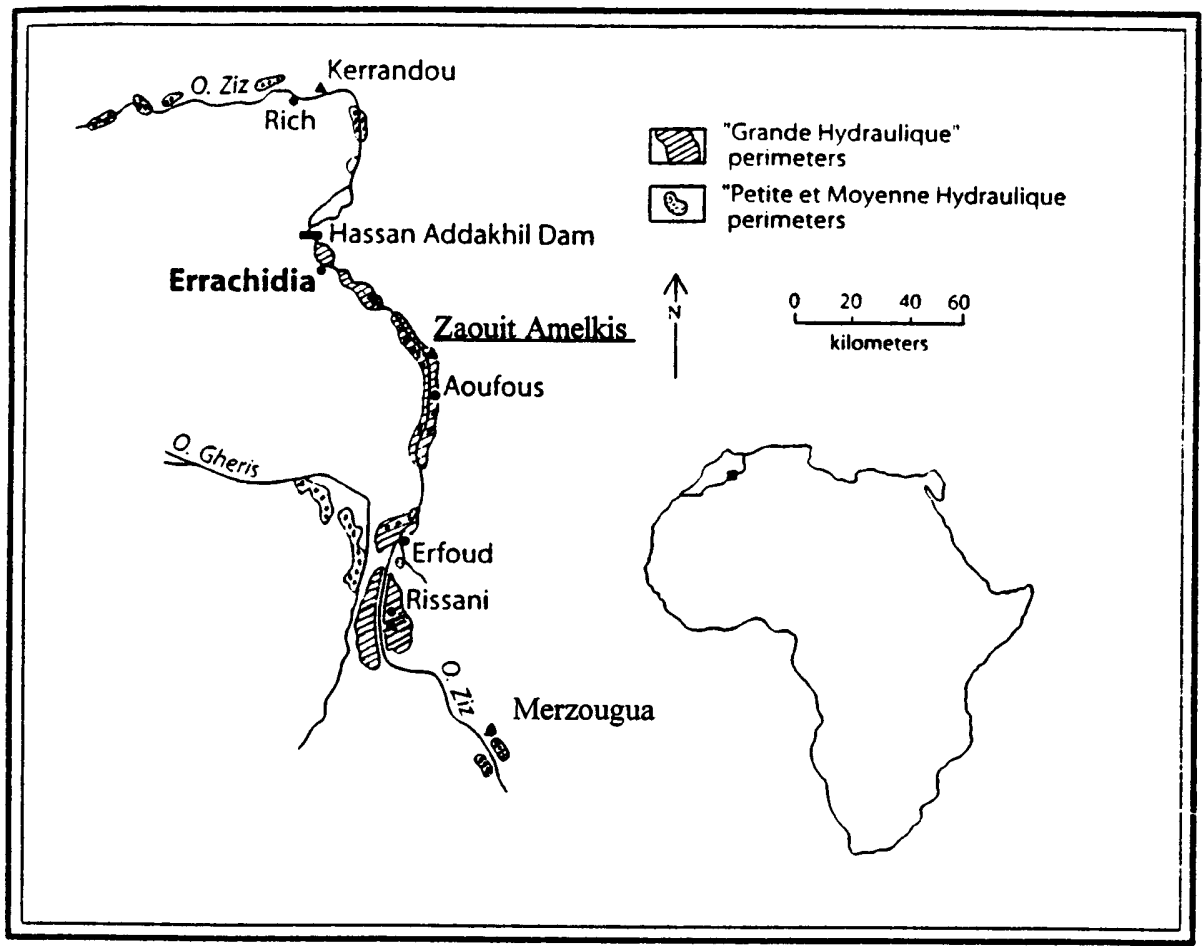

Figure 1. Irrigated Perimeters in the Ziz Valley, Morocco. Adapted from Welch, Mabry, and Ilahiane 1996:121.

In the Ziz Valley, the irrigation community is usually made up of one or several villages along the river sharing communal main canals that irrigate the palm grove. Each

1. R. Abdellaoui 1987; M. Aït-Hamza 1993; A. Bencherifa and H. Popp 1992; J. Berque 1978:143-45 and 153-55; N. Bouderbala et al. 1984; J. Chiapuris 1977:211-13; C. Geertz 1972:32-35; E. Gellner 1969; E. Glick 1970:172-74; A. Hammoudi 1985; D. Hart 1976:107-116, 1980, 1984; J. Miller 1984:77-86; M. Nadir 1980:126-36; L. Ouhajou 1993; P. Pascon 1978, 1979; J. Welch, J. Mabry, and H. Ilahiane 1996. 
village has a local council (taqbilt in Berber) that administers the economic, political, and social organization of the village. The border limits are known and recognized by neighboring villages. The management of water and land fall under the responsibility of the council. Typically, the main canal (targa in Berber) draws water from a diversion dam built out of dirt, sticks, and stones. The canal is considered the property of the village or the villages that use it and maintain its operation. The neighboring villages recognize each other's rights of ownership, construction, and maintenance duties.

The irrigation network of the village of Amelkis, for instance, could be described as a local folk model, or what Levi-Strauss calls the "home made model" (C. Lévi-Strauss 1953:327). The Amelkis palm grove stretches on both sides of the Ziz river. Thus, its system of irrigation is fed by two diversion dams, the Jarmonia dam on the west bank and the Salhiya on the east bank of the Ziz River. Each dam feeds a main canal: the Salhiya dam feeds the Salhiya canal on the east bank, and the Jarmonia dam feeds the Jarmonia canal on the west bank of the river. These two diversion dams are situated at about $7 \mathrm{Km}$ north of the village. The location of dams requires pacts with neighboring villages whose territories the canals traverse, as well as permitting topography and slope. For these reasons, and for the main canals' right of passage through the neighbors' lands, a tradition of weekly division of water regulates water use among the villages. The Salhiya canal on the east bank runs through the Lkenz, Amelkis, and Zwiwia villages and water distribution is performed on a weekly basis. Lkenz to the north of Amelkis uses its water share form sunset Saturday to sunset Sunday, Amelkis from sunset Sunday to sunset Friday, and Zwiwia to the south of Amelkis from sunset Friday to sunset Saturday. On the west bank of the river the Jarmonia canal traverses the villages of Bousaid, Amelkis, and Jramna. Bousaid, to the north of Amelkis, is entitled to use its water share from sunset Saturday to sunset Sunday, Amelkis from sunset Sunday to sunset Thursday, and Jramna, south of Amelkis, from sunset Friday to sunset Saturday. Water channeled through the main canals is the property of all members of the community and is everyone's concern. Breaking dams or diverting water illegally from the main canals has led to bloody disputes and water wars among the villages.

As the Jarmonia canal reaches Amelkis' fields, it channels water into the village's upper and lower targa, which in turn divide into secondary canals, and then into tertiary canals called lmsarf leading water straight to fields. Although the main canal is the responsibility of several villages, once within the boundaries of a village it becomes the business of all members of that village. The lower and upper targas are of concern to the whole village as well, whereas the secondary and tertiary canals are the responsibility of owners who get their water from them and, therefore, are in charge of their maintenance and repair. In some places, however, the main canal feeds directly into the tertiary canals. The same rules apply on the east side as on the west side. The system of water distribution in Amelkis is based upon the principle of mulk, or private ownership. Thus, the water that a person gets is as much their property just, as is their land property. The owners of the upper canal fields can take as much water as they wish without taking into account the interests of the lower canal field owners. This distribution of water is reinforced through the customary rule of the priority of the upper canal lands over the lower canal lands. Water rights are not alienable from land rights; nevertheless, water is still considered to be the outcome of collective obligations.

Land is divided into units of measurement called taggurt (plural tiggurin). After the settlement of the Ait Atta along the riverine villages of the Ziz Valley in the nineteenth century, the sum of tiggurin was the homestead share that each conquering lineage or 
households within each lineage were entitled to. Land holdings in the Ziz Valley are private property or aharmil in terms of its classification within the Ait Atta land tenure taxonomy. ${ }^{2}$ Before distributing land, the council along with the fqih and outside property assessors would set out to the palm oasis to evaluate the nature of terrain, surface areas, irrigation nodes and the depth of the water table. They then divide the valley, or relevant area, into a number of zones along the river banks: an upstream zone, a middle stream zone, and a lower stream zone.

A taggurt owner theoretically would have three igran (singular igr) or fields, or more, depending on the abundance of land, a piece in every zone. The character of each field was usually from the bank of the river, perpendicular to its axis, to the marginal and uncultivated lands of the valley, being shouldered by other tigurrin owners to the right and left. The field incorporates upstream lands irrigated by the main canal, then other lands irrigated by tertiary and secondary canals, and finally lands extending over the slopes above the valley and outside the irrigation network, an area called amardul. Fields thus extend from the river to the mountains; this diversified set of land property gave rise to the overly quoted Berber expression of establishing the rights of taggurt owner: sag islman ar udadn, "from the fish to the mouflons."

Capt. De Monts de Savasse pointed out (1951) that the concept of taggurt is one part land and one part water. It is of variable size and its dimensions are subject to a host of ecological variables such as location, annual precipitation, and the amount of labor needed to extend and develop the land. In the Ziz Valley, in particular in the Ait Atta villages, water rights are linked to rights of land. When land changes hands water rights follow the land. Distribution of irrigation water is based on the concept of mulliy or "turns." A "turn" of irrigation belonged to each household and applied to fields, and not to individual irrigation turns because, in the villages of the middle Ziz Valley there is enough water. Whereas the maintenance and clearing of the secondary and tertiary ditches is the responsibility of the beneficiaries, labor required for the upgrading and maintenance of the diversion dam and the main canals, the life line of the village, is provided on a pro rata basis by each taggura owner. The meticulous division of property into tigurrin measurement units along the three ecological zones of the valley is ingenious in maximizing each household's chances of benefiting from the scarce and variable supply of water.

Taggurt is a portfolio of land and water in the upper, middle, and lower reaches of the river estimated to provide the annual subsistence requirements of each takat or household. Despite changes in the original taggurt system that prohibited land fragmentation, taggurt has survived to our day and still remains the preferred local and traditional unit of water repartition and defines the expenses and duties of each owner in the operation and maintenance of the irrigation network of the ksar. In the Amelkis village, taggurt does not only refer to a standard unit of measuring land, but also evaluates olive and date production. It is equivalent an area taking 24 muds or 12 'abras of seeds, given that 1 'abra equals 2 muds -12 muds of seeds, and the other 12 for olives and palm dates. The

2. In general, the Ait Atta distinguish 4 types of land tenure or timizar: (1) mulk or aharmil refer to private property; (2) iguldan or pasture lands used by specific clans and subject to closing and opening regulations by the tribal confederations; (3) bil-khir or cultivated land that is not owned but used by the first conquering clans; and (4) $l-k h l a$ or empty wilderness belonging to the assembly and the community (D. Hart 1980:104). 
measurement of tree production differs from that of seeds. Tree production is measured in what is called lwatad. One lwatad of palm tree dates equals 10 'awint or $1 \mathrm{mud}$, and one ta' wint is equivalent to $1 \mathrm{~kg}$ of seeds or fruit produce. It follows from this that for canals and diversion dams maintenance, each taggurt is evaluated at 12 shhar or months and each month equals 2 muds of seeds or the combination of 1 lwatad and 1 mud of seeds. Tradition of the land stresses that every taggurt owner must provide an able-bodied man, and not a teenager, and a beast of burden with a container, preferably a mule, for work on the main canals and the diversion dams as need be.

The conceptualization of taggurt into 12 months makes provision for the mobilization of labor on a monthly basis to deal with the mishaps and the emergencies of the irrigation system. Small land owners who have shares of 2 muds must provide one able-bodied day of labor, and if an owner has less than 1.5 muds of seeds, it is suggested that he cooperate and trade labor days with another owner within his lineage for the completion of his monthly labor requirements. In times of emergencies, however, such as floods that usually damage the palm oasis and the irrigation infrastructure, the able-bodied of the whole village or people capable of fasting ramadan, regardless of land titles must participate in fixing the system. Every household must also bake an extra loaf of bread, and provide a bowl of olive oil to feed the irrigation labor (H. Ilahiane 1995).

\section{The Social Organization of the Irrigation System}

Social organization presupposes cooperation and resolution of conflict among members of the community as issues of private and communal property have to be regulated. The perpetuation of the Amelkis' folk model has relied heavily on the use of force and symbolic power rather than rules and norms of behavior agreed upon by the community. The maintenance and the perpetuation of the water system is the objective of the well-positioned segment of society.

Historically, for the Ait Khabbash Berbers, land tenure was the founding pillar of law and tradition, azerf. Land and tree tenure was virtually the decisive vehicle through which the Ait Atta's social organization expressed itself. Exclusion of outsiders was the chief operational element of the Ait Atta's construct of property, and the perpetuation of tamazirt or the patrimony of the community was jealously guarded by the keepers of customary law and tradition. Those who were not members of the Ait Atta and the holy Arab lineages, particularly the Haratine, could never acquire land in the Ait Atta land. Property was the primary cementing block of the "conservative closed corporate community," and was embedded in complex contexts of violence, ecology, power, and cultural concepts to keep outsiders and the conquered from accessing it. The concept of shafa ' $a$ or preemption, for instance, was and still is mobilized to block land transfers from Berber lineages to non-Ait Atta groups. Land tenure for the Ait Khabbash is referred to as al-asl, or origin and ancestry; in other words, origin, social structure, and identity were and are still writ large in property (R. De Monts de Savasse 1951; R. Dunn 1977; E. Gellner 1969; A. Hammoudi 1974; D. Hart 1980, 1984; L. Mezzine 1987).

As soon as the Berbers settled their accounts with the sedentary population of the village, they started dividing the lands among themselves. Mezzine describes the Ziz Valley's situation in the eighteenth and nineteenth centuries as follows:

Chez Ayt Atta pour lesquels le processus de sedentarisation est relativement recent(XVIIIe-XIXe siècles) la tradition orale rapporte que quand un groupe décide de s'installer, que ce soit d'ailleurs sur une terre vierge... Comme ce fut le cas au 
Rteb, la terre conquise était divisée en autant de parts qu'il y a de familles à installer. Ces parts étaient généralement, constituées de plusieurs bandes de terrain perpendiculaires à la vallée.... Chaque part comportait obligatoirement, une bande en amont, une autre au centre, et une troisième en aval pour permettre également une bonne partition de l'eau, et de la qualité de la terre sur les membres du groupe (L. Mezzine 1987:202). ${ }^{3}$

Among the Ait Atta for whom the sedentarization process is relatively recent (XVIIXIXth centuries, oral tradition states that when a group decided to settle, whether on virgin lands or not... As was the case in Rteb, conquered land was divided into as many shares as there were families to settle. These shares of land were generally made up of several fields perpendicular to the valley... Each share contained one field in the upstream, another in the middle stream, and a third in the downstream so as to guarantee an equal distribution of water and good quality land among the members of the group.

In the Amelkis village, another oral tradition reports that once the Ait Khabbash nomads conquered a village, the first thing that any member of the group did was to drive a claim stake on the property that happened to be before him or her. This is known as "wat tagut": to hammer a stake on a piece of land giving the member the automatic right of ownership regardless of who the past owner was. Before their sedentarization, the Ait Khabash nomads practiced transhumant migration between the Ziz Valley and the marginal grazing lands of the Anti and High Atlas mountains. The Shurfa and the Murabitin established their religious authority through preaching and persistent insistence upon their descendence from the Prophet and holy men.

The management of the irrigation system falls under the village council. The system is fixed and everyone knows the rules. The priority and access that Berbers and Arabs enjoy reflect their higher status in the community. For instance, in the constitution of 1883 of Lgara, a Berber dominated village in the middle of the Ziz Valley where the Haratine were institutionally blocked from owning or having access to the means of production, it was stipulated that, "If anyone sells a house to a Hartani the seller as well as the buyer will be fined one hundred mithqals each. Purchase of any sort of land by the Haratine is equally fined by the same amount." (L. Mezzine 1987:193, Section [21]).

For the maintenance of the dam, there is a yearly campaign on the village level to mobilize the work force to repair and fix the dam, the canal, and the major branches. Communal help is called upon when the dam is destroyed by floods. For the maintenance of the irrigation system, all males past the age of puberty have the obligation to take part in the upkeep of the dam regardless of whether they own land or not. The constitution of Lgara makes it obligatory that "when the shaykh demands the mobilization of youth labor for an irrigation maintenance task all the Haratine must be present. He who is absent is

3. This passage translates as follows: Among the Ait Atta for whom the sedentarization process is relatively recent (XVII-XIXth centuries), oral tradition states that when a group decided to settle, whether on virgin lands or not... As was the case in Rteb, conquered land was divided into as many shares as there were families to settle. These shares of land were generally made up of several fields perpendicular to the valley... Each share contained one field in the upstream, another in the middle stream, and a third in the downstream so as to guarantee an equal distribution of water and good quality land among the members of the group. 
fined 5 uqiyas." (L. Mezzine 1987:234, section [21]). Although the Haratine are landless their participation in the maintenance of the irrigation system is based on their low and subservient status in the village community.

In normal times, the work force provided by each holder is a function of their holdings. The Shurfa and Murabitin are usually exempt from this kind of work; "their Haratine volunteer" does their share. It is believed that by sparing the Shurfa and Murabitin from this menial work, the Haratine gain some "hassanat" (afterlife rewards) and a blessing that counts as a good point in paving the road to Heaven. The element of divine grace that the Shurfa possess or imagine owning induces the Haratine to perform labor for them. This divine power is also employed to contain the Haratine's compliance, and at the same time, to disengage, if not to arrest, any forms of social change and disobedience. The monopoly of divine power by the Shurfa and the Murabitin succeeds in extracting menial and agricultural labor form the Haratine that the Shurfa and Murabitin are exempt or pretend to be exempt from on the basis of their religious genealogy. The Berbers usually hire the Haratine to fulfill their share in the upkeep of the irrigation network. Water cheating and produce stealing from the palm grove and vegetable gardens are the two major sources of labor for the maintenance of the irrigation infrastructure in normal times. Theft tends to be high because almost all the Haratine are landless and they are barred from the right to cut and collect grass on the banks of the river and the canals as well as on parcel boundaries. While the landless Haratine are required to participate in the operation and maintenance of the irrigation infrastructure of the village, they are denied the right of use of wild grass and forbs patches found on the banks of the river and canals as well as on field boundaries. These grassy areas, particularly those on the banks of the river, are used by Berbers and Arabs to graze their mules and bovines. Blocking the Haratine from using what is supposedly communal property of the village, even though the Haratine must provide labor for the upkeep of the community's communal irrigation system, is justified by the high status groups on the principle that a villager who does not own or sharecrop property has no business going to the palm grove and the gardens. The offender is subject to a public denunciation from the minaret and later given the choice between feeding a party of 10 or 12 people for a lavish dinner (usually involving six members of the council, the fqih of the mosque, the prayer caller, the water and palm grove guards, and another member or two of the community), or one or two days community service clearing and cleaning the main canals so that water runs smoothly.

The dinner expenses are usually too stiff for the poor and landless to bear, and to save face he is compelled to negotiate his way through credit, which in turn, makes him indebted and dependent on his patrons. This practice of "feasting" is locally called $n$ ' $z u l$ from the Arabic verb "nazala" meaning to "fall on someone." The $n$ 'zul has a practical function which is to sanction the offenders and to teach others a lesson in communal administration and morality. The underlying motive however, is to bankrupt an offender, and at the same time to reinforce the religious ideology and power of Arabs and Berbers, and to perpetuate the vulnerability and dependence of the landless Haratine. The water guard and the palm grove guard are paid in kind for their community service, besides their prestigious position in the council's circle, and they are entitled to the tithe of the harvest (cereals, dates, and olive oil) delivered to them on the day of 'id al-fitr (the day of breaking the fast).

Recently, however, access to land by the low status Haratine has been facilitated by revenue streams linked to migration to Europe. Certainly, the Haratine have accumulated more land over the last two decades ( 22 percent of the village's private land) and have 
harvested more economic and political representation at the local and regional levels. They have slowly repudiated the patron-client society and have hailed the opportunity to migrate. In fact, it seems that the Haratines' drive to amass land could only be understood in connection with the policies of the colonial and postcolonial state and remittances from Europe. Though a few Berbers and Arabs have migrated, they have adopted western consumption patterns, thereby taxing their participation in land investments. What is interesting, however, about present day social changes sweeping the Ziz Valley is that the Haratine are using their new wealth to short-circuit the traditional barriers of access to resources and appropriate what is inherently a Berber cultural concept, al-asl or land, to construct a multiplicity of cultural and power bases to challenge the traditional cultural hegemony of the Berbers and the Arabs.

Although the Haratine have been successful in acquiring land, they still run into difficulty at a number of levels. These socioeconomic and political changes are, however, silently resisted by the declining traditional nobility. This nobility is being forced to "eat its fields" and al-asl, one by one, to meet its subsistence and "ceremonial" funds and to face up to the new demands of the community's cultural economy of jealousy. These dynamics of social mobility, though interesting, are beyond the scope of this paper.

In conclusion, in the mulk system of Amelkis, it seems that the maintenance of the irrigation system is not only governed by social relationships, but rather subject to intracommunity relationships designed to disguise the extortion of collective labor, especially when the level of technology and resource management techniques are simple, yet demand communal participation. The combination of the Berber use of force and the Arabs' mobilization of their holy genealogy legitimized through ethnic stratification succeeded, over time, in naturalizing and reproducing the process of exploitation of the Haratine's labor, while also forming "la forme la plus précieuse d'accumulation" for the high status Berbers and Arabs in the Saharan frontier of the Ziz Valley (P. Bourdieu 1972:178, 237-239).

\section{Acknowledgments}

I would like to thank the National Science Foundation and the Wenner-Gren Foundation for Anthropological Research for support of my dissertation fieldwork in Morocco and France (1994-1995). I would like also to thank the inhabitants and the members of the taqbilt or council of the village of Zaouit Amelkis for their cooperation and for helping one of their own, and the Office Regional de Mise en Valeur Agricole du Tafilalet (ORMVAT) for their support and institutional affiliation. Many thanks go to Tad Park, Tom McGuire, Charles Stockton, Moh Rejdali and Nabil Chbouki (IAV Hassan II), Abrou Hro (ORMVAT) and the late Bob Netting for their valuable input and encouragement. Special thanks also go to the anonymous reviewers for their superb guidance.

\section{References Cited}

Abdellaoui, R. M.

1987. Small-Scale Irrigation Systems in Morocco. In Public Intervention in FarmerManaged Irrigation Systems, edited by IIMI, pp. 165-174. Digana Village, Sri Lanka: IIMI. 
Aït-Hamza, M.

1993. Irrigation et Stratification Socio-Spatiale dans une Oasis sans Palmier: Le Cas du Dades. In Aspects de l'Agriculture Irriguée au Maroc, edited by M.A. Alaoui and P. Carrière, pp. 71-85. Rabat, Morocco: Publications de la Faculté des Lettres et des Sciences Humaines.

Arnould, E.

1990. Barriers to Sustained Development: Embedded Institutions and Arid Resources Management. Office of Arid Lands Newsletter 21:7-13.

ANAFID

1990. Gestion des Grands Périmetres Irrigués au Maroc, vol. 1. Distribution de l'Eau d'Irrigation. Rabat: Association Nationale des Oeuverages d'Irrigation.

1991. L'Irrigation au Maroc. Rabat: ANAFID.

Bencherifa, A. and H. Popp

1992. L'Oasis de Figuig: Persistence et Changement. Passau, Germany: Département de Géographie de l'Université de Passau.

Berque, J.

1978. Structures Sociales du Haut-Atlas. Paris: Presses Universitaires de France.

Bouderbala, N, J Chiche, A. Herzinni, P. Pascon

1984. La Question Hydraulique. Rabat, Morocco: Institut Agronomique et Vétérinaire Hassan II.

Bourdieu, P.

1972. Esquisse d'une Théorie de la Pratique: Pécédé de Trois Etudes d'Ethnologie Kabyle. Genève: Librairie Droz.

Chambers, R.

1989. Editorial Introduction: Vulnerability, Coping, and Policy. IDS Bulletin 20 (2): 110.

Chiapuris, J. P.

1977. The Ait Ayash of the Central Atlas: A Study of Social Organization in Morocco.

Doctoral Dissertation, University of Michigan Dept. of Anthropology. Ann-Arbor: University Microfilms.

De Monts de Savasse, R.

1951. Le Régime Foncier chez les Ait Atta du Sahara. Paris: Centre des Hautes Etudes sur l'Afrique et l'Asie Modernes (CHEAM).

Dunn, R.

1972. Berber Imperialism: the Ait Atta Expansion in Southeast Morocco. In Arabs and Berbers: From Tribe to Nation in North Africa, edited by E. Gellner and C. Micaud, pp. 85-107. Lexington, Mass: D.C. Heath and Co.

1977. Resistance in the Desert. Madison, Wisconsin: University of Wisconsin Press.

Geertz, C.

1972. The Wet and the Dry: Traditional Irrigation in Bali and Morocco. Human Ecology 1(1):23-29.

Gellner, Ernest

1969. The Saints of the Atlas. Chicago: Chicago University Press.

Glick, T.

1970. Irrigation and Society in Medieval Valencia. Cambridge, Mass: Cambridge University Press. 
Hammoudi, A.

1974. Segmentarité, Stratification Sociale, Pouvoir Politique et Sainteté: Réflexions sur les Thèses de Gellner. Hespéris 15:147-180.

1985. Substance and Relation: Water Rights and Water Distribution in the Dra'a Valley. In Property, Social Structure and Law in the Modern Middle East, edited by A. Mayer, pp. 27-57. Albany, New York: State University of New York Press.

Hart, D. M.

1976. The Ait Waryaghar of the Moroccan Rif: An Ethnography and History. Tucson, Arizona: University of Arizona Press.

1980. Dadda Atta and his Forty Grandsons: The Socio-Political Organization of the Ait Atta of Southern Morocco. Cambridge, England: Menas Press Ltd. 1984. The Ait Atta of Southern Morocco. Cambridge, England: Menas Press Ltd.

Ilahiane, $\mathrm{H}$.

1995. Fieldwork Notes on file with the author.

Ilahiane, H., Mabry, J. and Welsh, J.

1991. Rapid Rural Appraisal of Moroccan Irrigation Systems: Methodological Lessons from the Pre-Sahara. Report submitted to USAID/Rabat, Morocco.

Jacques-Meunié, D.

1958. Hiérarchie Sociale au Maroc Présaharien. Hespéris 45: 239-270.

Lévi-Strauss, C.

1953. Social Structure. In Anthropology Today, edited by A. L. Kroeber. Chicago: University of Chicago Press.

Mezzine, L.

1987. Le Tafilalet: Contribution à l'Histoire du Maroc aux XVII et XVIII Siècles. Rabat, Morocco: Publications de la Faculté des Lettres et des Sciences Humaines.

Miller, J.

1984. Imlil: A Moroccan Mountain Community in Change. Boulder and London:

Westview Press.

Ministère du Plan

1995. Preliminary Results of the 1994 Population and Housing, South-Central Morocco. Meknes, Morocco.

Nadir, M.

1980. Lecture de l'Espace Oasien. Paris: Sindbad.

ORMVAT

1989. Office Regional de Mise en Valeur Agricole du Tafilalet. Public Information Brochure Distributed in Errachidia, Morocco.

1991. Dossier Synoptique Portant sur l'Evolution des Principales Productions et Actions Agricoles, 1972-73 à 1989-1990. Document on file with the author and ORMVAT Office of Agricultural Production.

Ouhajou, L.

1993. Les Rapports Sociaux Liés aux Droits d'Eau: Le Cas de la Vallée de Dra. In Aspects de l'Agriculture Irriguée au Maroc, edited by M.A. Alaoui and P. Carrière, pp. 87-98. Rabat, Morocco: Publications de la Faculté des Lettres et des Sciences Humaines.

Pascon, P.

1978. De l'Eau du Ciel à l'Eau d'Etat: Psychologie de l'Irrigation. Hommes, Terre et Eaux 8 (28): 3-10. 
1979. Théorie Générale de la Distribution des Eaux et de l'Occupation des Terres dans le Haouz de Marrakech. Revue de Géographie du Maroc 18: 3-19.

Welch, J., Mabry, J. and Ilahiane, H.

1996. Rapid Rural Appraisal of Arid Land Irrigation: A Moroccan Example. In Canals and Communities: Small-Scale Irrigation Systems, edited by J. Mabry, pp. 119-138. Tucson, Arizona: The University of Arizona Press.

\begin{abstract}
This paper examines the social organization of a small-scale irrigation system in a multiethnic setting in the Ziz Valley, southeast Morocco. It is focused on the analysis of the Zaouit Amelkis village irrigation system and its management. The village of Zaouit Amelkis paints a complex historical and ecological picture where ethnicity, power, and religious ideology function to manage local resources. This paper claims that the traditional land owning groups, Arabs and Berbers have, over time, extorted labor from the landless, low-status group, the Haratine, for the operation and maintenance of the village's irrigation system.
\end{abstract}

Key words: ethnicity, water management, land tenure, Southeast Morocco.

\title{
Résumé
}

Cet article examine l'organisation sociale d'un système d'irrigation à petite échelle dans un contexte multi-ethnique dans la Vallée de Ziz, au Sud-est du Maroc. Il mis au point l'analyse de la gestion du système d'irrigation du village de Zaouit Amelkis. Le village de Zaouit Amelkis expose une situation historique et écologique complexe où ethnicité, pouvoir et idéologie religieuse fonctionnent à gérer les ressources locales. Cet article prétend que les groupes traditionnels de proprietaires, Arabes et Berbères ont extorqué, avec le temps, la main-d'oeuvre des sans terres, groupe de la classe inférieure, les Haratines, pour le fonctionnement et l'entretien du système d'irrigation du village.

Mots clés: l'ethnicité, gestion hydraulique à petite échelle, régime foncier, Sud-est Marocain.

\section{Resumen}

Este artículo examina la organización social de un sistema de riego de pequeña escala dentro de un contexto multiétnico en el Valle de Ziz en el sudeste de Marruecos. Se enfoca en el análisis del sistema de riego del pueblo de Zaouit Amelkis y su manejo. Se pinta un cuadro de una historia y ecología compleja en que etnicidad, poder, e ideología religiosa funcionan en el manejo de recursos locales. Este artículo propone que los tradicionales grupos de terratenientes, o sea los Arabes y los Berberes han, atreves de tiempo, extorsionado labor de los grupos sin tierras, los de bajo rango social como los Haratine, para la operación y mantenimiento del sistema de riego del pueblo.

Palabras claves: etnicidad, manejo de aguas, tenencia de tierras, el Sudeste de Marruecos. 